\title{
Limbic Seizures Induce P-Glycoprotein in Rodent Brain: Functional Implications for Pharmacoresistance
}

\author{
Massimo Rizzi, ${ }^{1}$ Silvio Caccia, ${ }^{1}$ Giovanna Guiso, ${ }^{1}$ Cristina Richichi, ${ }^{1}$ Jan A. Gorter, ${ }^{4}$ Eleonora Aronica, ${ }^{5}$ \\ Marisa Aliprandi, ${ }^{1}$ Renzo Bagnati, ${ }^{2}$ Roberto Fanelli, ${ }^{2}$ Maurizio D'Incalci, ${ }^{3}$ Rosario Samanin, ${ }^{1 \dagger}$ and \\ Annamaria Vezzani ${ }^{1}$ \\ Departments of ${ }^{1}$ Neuroscience, ${ }^{2}$ Environmental Health Sciences, and ${ }^{3}$ Oncology, Istituto di Ricerche Farmacologiche \\ "Mario Negri," 20157 Milano, Italy, ${ }^{4}$ Swammerdam Institute for Life Sciences, University of Amsterdam, 1098 SM, \\ Amsterdam, The Netherlands, and ${ }^{5}$ Department of (Neuro)Pathology, Academic Medical Center, University of \\ Amsterdam, 1105 AZ, Amsterdam, The Netherlands
}

The causes and mechanisms underlying multidrug resistance (MDR) in epilepsy are still elusive and may depend on inadequate drug concentration in crucial brain areas. We studied whether limbic seizures or anticonvulsant drug treatments in rodents enhance the brain expression of the MDR gene ( $m d r)$ encoding a permeability glycoprotein (P-gp) involved in MDR to various cancer chemotherapeutic agents. We also investigated whether changes in P-gp levels affect anticonvulsant drug concentrations in the brain. Mdr mRNA measured by RT-PCR increased by $85 \%$ on average in the mouse hippocampus 3-24 hr after kainic acid-induced limbic seizures, returning to control levels by $72 \mathrm{hr}$. Treatment with therapeutic doses of phenytoin or carbamazepine for $7 \mathrm{~d}$ did not change $m d r$ mRNA expression in the mouse hippocampus 1-72 hr after the last drug administration. Six hours after seizures, the brain/plasma ratio of phenytoin was reduced by $30 \%$ and its extracellular concentration estimated by microdialysis was increased by twofold compared with control mice. Knock-out mice (mdr1a/b -/-)

Approximately $30 \%$ of patients with epilepsy develop intractable seizures [i.e., seizures persist despite accurate diagnosis and carefully monitored treatment with antiepileptic drugs (AEDs)] (Collaborative Group for the Study of Epilepsy, 1992; Cockerell et al., 1995). The mechanisms underlying multidrug resistance (MDR) in epilepsy are still elusive. Some risk factors have been identified in patients, (i.e., time of onset of epilepsy, type and etiology of seizures, and number of seizures before the start of the treatment) (Reynolds, 1987; Hauser and Hesdorffer, 1990; Collaborative Group for the Study of Epilepsy, 1992); however, they do not provide a convincing explanation of why and how a subset of patients is drug-refractory. It is likely that MDR is a multifactorial phenomenon that includes both pharmacodynamic and pharmacokinetic mechanisms. It has been hypothesized that the changes in the electrical and synaptic properties of neurons

Received March 18, 2002; revised April 23, 2002; accepted April 23, 2002.

This work was supported by Telethon Onlus Foundation Grant E.0823 and by a Programma Ricerca Finalizzata grant. We regret to announce that Dr. Rosario Samanin, a dear colleague and outstanding scientist, passed away in June of 2001.

$\dagger$ Deceased, June 5, 2001.

Correspondence should be addressed to Dr. Annamaria Vezzani, Laboratory of Experimental Neurology, Department of Neuroscience, Istituto di Ricerche Farmacologiche "Mario Negri," Via Eritrea 62, 20157 Milano, Italy. E-mail: Vezzani@ marionegri.it.

Copyright (C) 2002 Society for Neuroscience $\quad 0270-6474 / 02 / 225833-07 \$ 15.00 / 0$ lacking $\mathrm{P}$-gp protein showed a $46 \%$ increase in phenytoin concentrations in the hippocampus 1 and $4 \mathrm{hr}$ after injection compared with wild-type mice. A significant $23 \%$ increase was found in the cerebellum at $1 \mathrm{hr}$ and in the cortex at $4 \mathrm{hr}$. Carbamazepine concentrations were measurable in the hippocampus at $3 \mathrm{hr}$ in $m d r 1 \mathrm{a} / \mathrm{b}-/-$ mice, whereas they were undetectable at the same time interval in wild-type mice. In rats having spontaneous seizures 3 months after electrically induced status epilepticus, mdr 1 mRNA levels were enhanced by 1.8-fold and fivefold on average in the hippocampus and entorhinal cortex, respectively. Thus, changes in P-gp mRNA levels occur in limbic areas after both acute and chronic epileptic activity. P-gp alterations significantly affect antiepileptic drugs concentrations in the brain, suggesting that seizure-induced mdr mRNA expression contributes to MDR in epilepsy.

Key words: anticonvulsant drugs; epilepsy; mdr; P-glycoprotein; rat; seizures

induced by epileptogenesis in specific brain areas make the epileptic tissue less susceptible to the action of AEDs (Sashihara et al., 1992; Lombardo et al., 1996). Etiological factors in the embryonic period interfering with the differentiation and neuronal migration of neurons (i.e., cerebral dysplasia) are often associated with pharmacoresistant forms of epilepsy (Spreafico et al., 1998). MDR in epilepsy may also depend on an inadequate intraparenchimal AED concentration. This may occur if AEDs are actively extruded from the brain after their entry through the vascular bed. In this regard, MDR to various chemotherapeutic agents in mammalian tumor cells has been suggested to depend on the increased expression and activity of a membrane-located permeability glycoprotein (P-gp) (Juliano and Ling, 1998) extruding with an energy-dependent mechanism a wide range of structurally unrelated, amphiphilic or hydrophobic drugs from the cell (Endicott and Ling, 1989).

Using epithelial cell lines expressing P-gp and in vivo microdialysis experiments in rats, it has been shown that phenytoin and carbamazepine are substrates of this pump (Tishler et al., 1995; Schinkel et al., 1996; Potschka et al., 2001), and that other AEDs have a structure compatible with being substrates of the P-gp (Morrow and Cohen, 1988). P-gps are encoded by small gene families, MDR1 and MDR3 in humans and $m d r 1 a, m d r 1 b$, and $m d r 2$ in rodents. MDR1, $m d r 1 a$, and $m d r 1 b$ cDNA confer MDR. 
P-gps encoded by MDR1 and $m d r 1 a$ and $m d r 1 b$ genes are highly concentrated in capillary blood vessels of the brain and in secretory epithelia of peripheral organs (Thiebaut et al., 1987; Croop et al., 1989; Tishler et al., 1995). The lack of P-gp in $m d r 1 a / b-/-$ mice affects drug transport into the brain more than in any other peripheral organ (Schinkel et al., 1994). The normal function of this transporter appears to involve steroid secretion, transepithelial and transendothelial transport of toxic xenobiotics, or certain endogenous metabolites and cytokines (Gottesman and Pastan, 1993).

It has been reported recently that the levels of mRNA of the MDR1 gene encoding P-gp were enhanced more than ten times in brain tissue surgically removed from patients with pharmacoresistant epilepsy (Tishler et al., 1995). In addition, enhanced immunostaining in astrocytes and in neurons was found in human brains from drug-refractory epileptic patients with malformations of cortical development (Sisodiya et al., 1999, 2001) or tuberous sclerosis (Lazarowski et al., 1999). One report has also shown increased immunoreactivity in glia $1 \mathrm{~d}$ to 2 weeks after intracerebral kainate injection in rats (Zhang et al., 1999).

Seizures of particular intensity and duration may change the expression of proteins both in neurons and glia in specific brain areas and alter the permeability properties of the blood-brain barrier (Nitsch et al., 1986). Moreover, chronic treatment with drugs acting in the CNS can modify the density and/or affinity of the respective receptor proteins in the brain. Although P-gp cannot be regarded as a classical receptor protein, the transported drugs have specific binding sites on its domains (Endicott and Ling, 1989; Gottesman and Pastan, 1993; Martin et al., 2000).

Thus, this study addressed three major points: (1) whether mrd1 mRNA expression in rodent brain was enhanced by acute seizures and chronic epileptic activity, (2) whether $m d r 1$ mRNA expression in rodent brain was enhanced by repetitive AED treatment, and (3) whether P-gp levels effectively influence AED concentrations in the brain. To this aim, we used transgenic mice lacking P-gp and rodent brain tissue overexpressing this transport pump.

Our results suggest that upregulation of P-gp in the brain after seizures may contribute to MDR in epilepsy.

\section{MATERIALS AND METHODS}

\section{Animals}

C57BL/6 male adult mice (25 gm) and Sprague Dawley male rats (250$350 \mathrm{gm}$ ) (Charles River, Calco, Italy) were used. The $m d r 1 a / b-/-$ mice and their wild-type littermates were purchased from Taconic (Germantown, MD). These are homozygous mice lacking both isoforms of the $m d r 1$ gene; therefore, these mice are deficient in P-gp (Schinkel et al., 1994).

The animals were housed at constant temperature $\left(21 \pm 1^{\circ} \mathrm{C}\right)$ and relative humidity (60\%) under a fixed $12 \mathrm{hr}$ light/dark cycle. Food and water were available ad libitum. Procedures involving mice or rats and their care were conducted in conformity with institutional guidelines that were in compliance with national (4 Decreto Legislativo 116, Gazzetta Ufficiale, suppl 40, 18-2-1992) and international laws and policies (European Economic Community Council Directive 86/609, Office Journal L 358, 1, 12 December 1987; National Institutes of Health Guide for the Care and Use of Laboratory Animals, U.S. National Research Council 1996).

\section{Seizure induction in mice}

Limbic seizures were induced in C57BL/6 mice by intraperitoneal injection of $30 \mathrm{mg} / \mathrm{kg}$ kainic acid (Tocris Cookson, Bristol, UK). Seizures were observed behaviorally, and only mice with recurrent stage 4-5 seizures (Racine, 1972) for at least $90 \mathrm{~min}$ (observation period) were used for subsequent biochemical assessments.

Mice were decapitated at various times (3-72 hr) after seizure onset
$(17.2 \pm 0.9 \mathrm{~min})(n=5$ mice each experimental group $)$. Various brain areas (hippocampus, cortex, and cerebellum) were used for RT-PCR analysis of $m d r 1$ mRNA.

\section{Self-sustained limbic status epilepticus in rats}

For hippocampal EEG recording and angular bundle stimulation, two pairs of insulated stainless steel electrodes were implanted under electrophysiological control. The procedures of electrode implantation, seizure induction, and continuous EEG measurements using seizure detection software have been described previously (Gorter et al., 2001). Briefly, the rats underwent a series of tetanic stimulations $(50 \mathrm{~Hz})$ of the hippocampus in the form of a train of pulses every $13 \mathrm{sec}$. Each train consisting of biphasic pulses (pulse duration, $0.5 \mathrm{msec}$; maximal intensity, $500 \mu \mathrm{A}$ ) had a duration of $10 \mathrm{sec}$. Stimulation was stopped when the rats displayed sustained forelimb clonus and salivation for minutes (within 60 min from beginning of stimulation). Usually, immediately after the termination of the stimulation, periodic epileptiform discharges (PEDs) at a frequency of 1-2 Hz were evident in the hippocampal EEG. PEDs continued to be displayed for at least $4 \mathrm{hr}$ after the end of tetanic stimulation [defined as status epilepticus (SE)]. We did not include a definition of the occurrence of behavioral seizures in SE, because such seizures could have a variety of forms of appearance, whereas the EEG criterion was more reliable. Rats in which the electrical stimulation did not induce SE were defined as belonging to the non-SE group.

SE rats $(n=6)$ and non-SE rats $(n=5)$ were placed under continuous EEG monitoring for $24 \mathrm{hr} / \mathrm{d}$ for as long as 3-4 months as described previously (Gorter et al., 2001).

Sham-operated control rats $(n=6)$ were implanted with electrodes and handled in the same way but were not stimulated. After EEG recording, rats were disconnected and decapitated.

RT-PCR analysis of $m d r$ mRNA was performed on samples of the stimulated hippocampus and the contralateral entorhinal cortex of sham $(n=6)$ and post-SE $(n=6)$ rats 3 months after electrical stimulation. One group of rats that did not develop SE but experienced only several clonic seizures during stimulation (non-SE rats; $n=5$ ) was also evaluated 3 months after stimulation.

\section{AED treatment}

Phenytoin and carbamazepine were given intraperitoneally in mice at 30 and $15 \mathrm{mg} / \mathrm{kg}$, respectively (dissolved in saline alkalinized with $0.1 \mathrm{~N}$ $\mathrm{NaOH}$ ). These doses are within the range of those effective in rodent models of epilepsy (Frey and Janz, 1985). AEDs were administered twice a day $8 \mathrm{hr}$ apart for $7 \mathrm{~d}$. Experimental and vehicle-injected mice $(n=5$ for each group) were killed 1-72 hr after the last drug administration for AED or mRNA measurements. The $1 \mathrm{hr}$ time-point was chosen to measure $m d r 1$ mRNA when maximal concentrations of the AEDs were reached in the tissue. AED treatment was stopped at the seventh day of administration because mice showed signs of toxicity if the treatment was prolonged further (i.e., decreased locomotion, drowsiness, and loss of weight).

\section{mdr1 mRNA measurements}

Total RNA was isolated from mouse or rat tissue according to the acid guanidinium-phenol-chloroform method (Bendotti et al., 1991). After the extraction, $1 \mu \mathrm{g}$ of total RNA was used as a substrate for singlestranded cDNA synthesis using murine leukemia virus reverse transcriptase $(50 \mathrm{U} / \mu \mathrm{l}$; PerkinElmer, Emeryville, CA), random hexamers (2.5 $\mu \mathrm{M})$, and deoxyNTP mix $(1.25 \mathrm{~mm}$ each) in a final volume of $20 \mu \mathrm{l}$. The mixture was incubated at room temperature for $10 \mathrm{~min}$, at $42^{\circ} \mathrm{C}$ for 15 $\mathrm{min}$, at $99^{\circ} \mathrm{C}$ for $5 \mathrm{~min}$, and at $5^{\circ} \mathrm{C}$ for $5 \mathrm{~min}$. An aliquot $(10 \mu \mathrm{l})$ of the cDNA synthesis mixture was used for PCR to amplify the cDNAs encoding for $\beta$-actin (used as internal control for cDNA added to the PCR) and rodent $m d r 1$. The PCR primers used are shown in Table 1.

Primer extension was performed with $1.25 \mathrm{U}$ of AmpliTaq DNA polymerase (PerkinElmer) in a final volume of $50 \mu \mathrm{l}$. Denaturing, annealing, and extension steps were performed at $95^{\circ} \mathrm{C}$ for $1 \mathrm{~min}$, at $60^{\circ} \mathrm{C}$ for $1 \mathrm{~min}$, and at $72^{\circ} \mathrm{C}$ for $1 \mathrm{~min}$ in a thermocycler (Omn-E; Hybaid, Ashford, UK). After the PCR, one-half of the product was loaded onto a $1 \%$ agarose gel stained with ethidium bromide and the resulting bands were quantitated by densitometry using an Image Master video documentation system (Pharmacia Biotech, Sunnyvale, CA) and ImageQuant version 1.2 software (Molecular Dynamics, Sunnyvale, CA). Optical densities of all $m d r l$ bands were normalized to the corresponding $\beta$-actin levels (Fig. 1). 


\begin{tabular}{lll}
\hline Table 1. Sequences of primers used in RT-PCR experiments \\
Primer name & Sense sequence $\left(5^{\prime}-3^{\prime}\right)$ & Antisense sequence $\left(5^{\prime}-3^{\prime}\right)$ \\
\hline Mouce $m d r 1$ & TACAGAAAGTAAGCTGTG & ATCCTGTCTCAGCATGGATT \\
Rat $m d r 1$ & GGCATATTCGGGATGTTG & CATGCACAGCTTGTCAAGC \\
$\beta$-actin & CACACTGTGCCCATCTACA & CACAGGATTCCATACCCAG
\end{tabular}

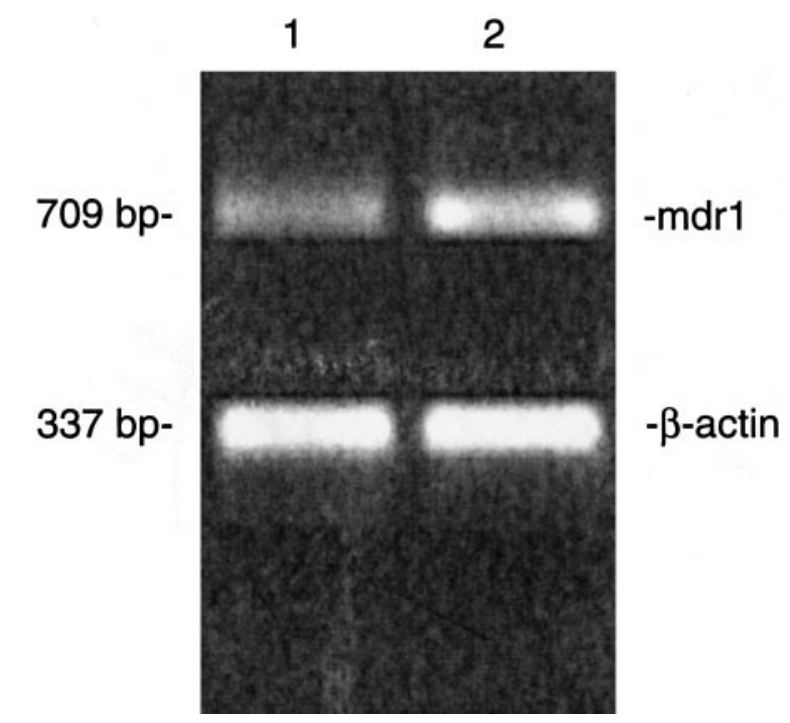

Figure 1. Representative agarose gel showing PCR amplification products from the mouse hippocampus $24 \mathrm{hr}$ after saline injection (lane 1) or $30 \mathrm{mg} / \mathrm{kg}$ kainic acid injection (lane 2). Each sample was amplified as described in Materials and Methods. Note the increased level of $m d r 1$ mRNA in the mouse treated with kainic acid (lane 2) compared with the control mouse (lane 1).

\section{Microdialysis experiment}

C57BL/6 mice were anesthetized with Equithesin (1\% phenobarbital/4\% chloral hydrate; $3.5 \mathrm{ml} / \mathrm{kg}$, i.p.; Sigma, St. Louis, MO) and placed in a stereotaxic apparatus (David Kopf Instruments, Tujunga, CA). During surgery, the mouse skull was exposed and two holes were made at the level of the dorsal hippocampus. A vertical dialysis probe with a $1 \mathrm{~mm}$ exchanging membrane (CMA10; Carnegie Medicine AB, Stockholm, Sweden) was positioned on each side to reach the dorsal hippocampus (coordinates from bregma: anteroposterior, -1.9 ; lateral, $\pm 1.5 ;-1.5$ below the dura). Each probe was perfused with artificial CSF at the constant rate of $1 \mu \mathrm{l} / \mathrm{min}$. The perfusate was discarded during the first 30 $\mathrm{min}$, and then three consecutive $30 \mathrm{~min}$ samples were collected, one before (blank) and two after phenytoin injection ( $30 \mathrm{mg} / \mathrm{kg}$, i.p.) to cover the time at which phenytoin concentrations were maximal in the tissue. This protocol was applied to mice $6 \mathrm{hr}$ after receiving an intraperitoneal injection of saline $(n=5)$ or $30 \mathrm{mg} / \mathrm{kg}$ kainic acid $(n=5)$. This was the time of maximal $m d r 1$ mRNA expression after kainate injection.

At the end of the dialysis experiment, the fibers were withdrawn from the tissue and the mice were decapitated. Both hippocampi were rapidly dissected out, and plasma was obtained from the blood for subsequent AED measurements (see below).

\section{AED measurements}

Brain tissue and plasma. Carbamazepine and its main metabolite 10,11carbamazepine-epoxide and phenytoin were determined in plasma and various brain areas by HPLC, after a liquid-liquid extraction procedure. Briefly, carbamazepine was measured in plasma samples $(0.2 \mathrm{ml})$ extracted twice with ethyl acetate $(1 \mathrm{ml})$ after adding the internal standard (mephenytoin) and $0.2 \mathrm{ml}$ of $0.5 \mathrm{M}$ phosphate buffer, $\mathrm{pH}$ 7.4. Phenytoin was measured in $0.2 \mathrm{ml}$ of plasma extracted with chloroform $(2 \mathrm{ml})$ after adding mephenytoin and $30 \mu \mathrm{l}$ of acetic acid. After centrifugation, the organic phases were separated and evaporated to dryness. The residues were dissolved in the mobile phase (see below) and analyzed by HPLC with UV detection $(210 \mathrm{~nm})$. Brain areas were homogenized $(10 \mathrm{ml} / \mathrm{gm})$ in methanol/water $(60: 40, \mathrm{v} / \mathrm{v})$ and processed as described for plasma.

Separation was done on a Spheri-5 RP18 column (PerkinElmer) (25 $\mathrm{cm} \times 4.6 \mathrm{~mm}$ inner diameter; $5 \mu \mathrm{m}$ particle size) at room temperature. The mobile phase was $0.01 \mathrm{M}$ phosphate buffer, $\mathrm{pH}$ 7.4: $\mathrm{CH} 3 \mathrm{CN}: \mathrm{CH} 3 \mathrm{OH}$ : $n$-butanol $(70: 15: 14: 1, \mathrm{v} / \mathrm{v})$, delivered at a flow rate of $1.2 \mathrm{ml} / \mathrm{min}$ (Liu et al., 1993).

The retention times were $\sim 32.5$ and $13.7 \mathrm{~min}$ for carbamazepine and its metabolite, respectively. The retention time was $31 \mathrm{~min}$ for phenytoin, $10.3 \mathrm{~min}$ for its metabolite 5-(4-hydroxyphenyl)-5-phenythoin, and 17 min for mephenytoin.

Standard curves were prepared daily by adding known concentrations of carbamazepine or phenytoin and their main metabolites to plasma or brain tissue from untreated mice. Linear regression analyses revealed correlation coefficients invariably exceeding 0.998 for all compounds. For carbamazepine and 10,11-carbamazepine-epoxide, the lower point of the calibration graph was $250 \mathrm{ng} / \mathrm{ml}$, using $0.2 \mathrm{ml}$ of plasma or brain homogenate. The lower point of the graph was $500 \mathrm{ng} / \mathrm{ml}$ for phenytoin and 250 $\mathrm{ng} / \mathrm{ml}$ for its metabolite using the same volume of tissues. At these concentrations, coefficients of variation for the precision of the assay were $<15 \%$, whereas higher concentrations gave values between 2 and $10 \%$ for all compounds in all tissues.

HPLC-mass spectrometry/mass spectrometry analysis of phenytoin in brain dialysate. Analysis of phenytoin was performed with an API 3000 triple quadrupole instrument (Applied Biosystems-Sciex, Thornhill, Ontario, Canada), interfaced with two Series 200 micro LC pumps (PerkinElmer) through a standard TurboIonSpray source (PerkinElmer). HPLC conditions were as follows: column: Luna C18, 3 $\mu \mathrm{m}, 2 \times 50 \mathrm{~mm}$ (Phenomenex, Chemtek Analitica, Bologna, Italy); flow: $0.2 \mathrm{ml} / \mathrm{min}$; eluent A: $0.01 \%$ formic acid in water; eluent B: acetonitrile; gradient: from $20 \% \mathrm{~B}$ to $70 \% \mathrm{~B}$ in $5 \mathrm{~min}$; loop: $20 \mu \mathrm{l}$. The HPLC effluent was directed to the mass spectrometry (MS) instrument through a splitting $\mathrm{T}$ connection that allowed reduction of the flow into the ion source to its optimal value (40 $\mu \mathrm{l} / \mathrm{min})$. MS conditions were as follows: source, TurboIonSpray in negative ion mode and with heater gas at $320^{\circ} \mathrm{C}$; ion spray voltage, $-4400 \mathrm{~V}$; orifice voltage, $-56 \mathrm{~V}$; ring voltage, $-240 \mathrm{~V}$; collision cell gas, nitrogen at a pressure of $2.6 \times 10^{-5}$ torr; collision energy, 30 electron volt (eV) (phenytoin) and $22 \mathrm{eV}$ (mephenytoin, internal standard). Quantitative analysis of phenytoin was done by multiple-reaction monitoring (MRM), measuring the fragmentation product $(\mathrm{m} / \mathrm{z} 102)$ of the deprotonated pseudo-molecular ion $(\mathrm{m} / \mathrm{z} 251)$. Mephenytoin was used as internal standard, by measuring a similar MRM transition $(\mathrm{m} / \mathrm{z} 217 \rightarrow \mathrm{m} / \mathrm{z} 188$ ). Calibration curves (typical $r \geq$ 0.990 ) were obtained by injecting standard solutions containing variable amounts of phenytoin (5-100 ng/ml) and a fixed amount of mephenytoin $(100 \mathrm{ng} / \mathrm{ml})$.

Dialysate samples were pooled from both hippocampi of each mouse and $20 \mu \mathrm{l}$ was spiked with $2 \mathrm{ng}$ of mephenytoin in $30 \mu \mathrm{l}$ of water/ acetonitrile 2:1 and transferred to the HPLC autosampler vials (PerkinElmer Series 200) for HPLC-MRM injections.

\section{Statistical analysis of data}

Data are means \pm SE ( $n=$ number of animals in each group). The effects of treatments were analyzed by one-way ANOVA followed by Tukey's or Mann-Whitney's test for unconfounded means.

\section{RESULTS}

Figure 1 shows a representative gel of RT-PCR amplification products stained with ethidium bromide from the hippocampi of control and experimental mice $24 \mathrm{hr}$ after kainic acid injection. The increase in the level of $m d r 1$ mRNA is evident in the animal treated with kainic acid (Fig. 1, lane 2) compared with the control mouse (Fig. 1, lane 1).

To investigate whether expression of $m d r 1$ mRNA in the brain was affected by acute seizure activity, we performed a detailed time course of changes after kainic acid injection in mice using RT-PCR (Fig. 2).

Between 3 and $24 \mathrm{hr}$ after the onset of limbic seizures, the hippocampal levels of $m d r 1$ mRNA were increased by $85 \%$ on average ( $p<0.01 ; n=5$ mice for each group), returning to control levels by $72 \mathrm{hr}$. Mdr1 mRNA was not significantly modified in the cerebellum or cortex $6 \mathrm{hr}$ after seizures (data not shown). 


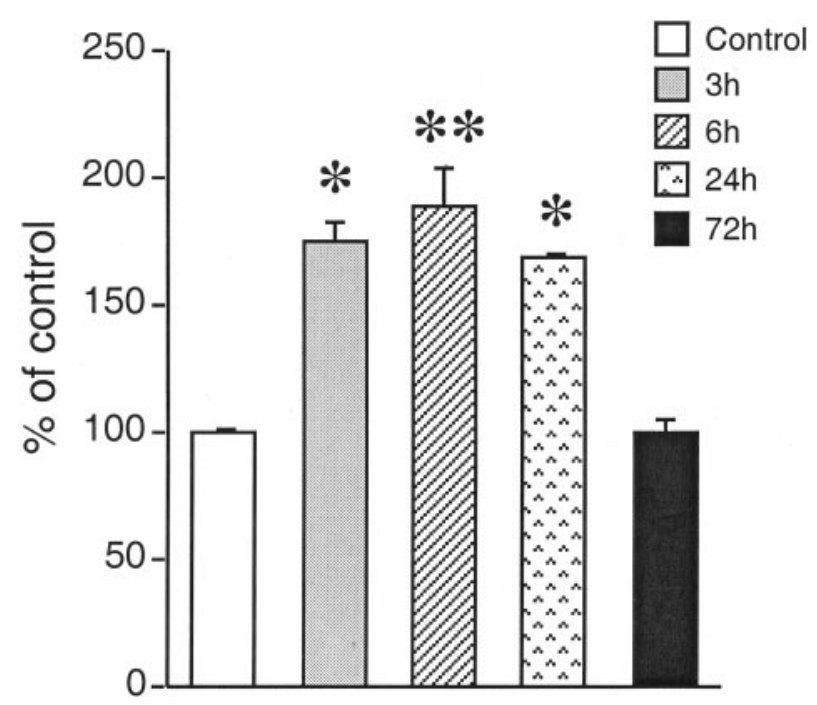

Figure 2. Time course of changes in $m d r 1$ mRNA levels in the mouse hippocampus after kainic acid-induced seizures. Data are means $\pm \mathrm{SE}$ $(n=5)$ of optical density values of gel bands representing PCR amplification products of $m d r 1$ mRNA normalized to the corresponding $\beta$-actin band used in each sample as an internal standard. The early time point (i.e., $3 \mathrm{hr}$ ) corresponds to $\sim 1 \mathrm{hr}$ after termination of seizures. Values in treated animals are expressed as a percentage of control levels [salineinjected mice killed at the various times $(n=5$ for each group) were pooled because they did not differ]. ${ }^{*} p<0.05$; ${ }^{*} p<0.01$ by MannWhitney's test.

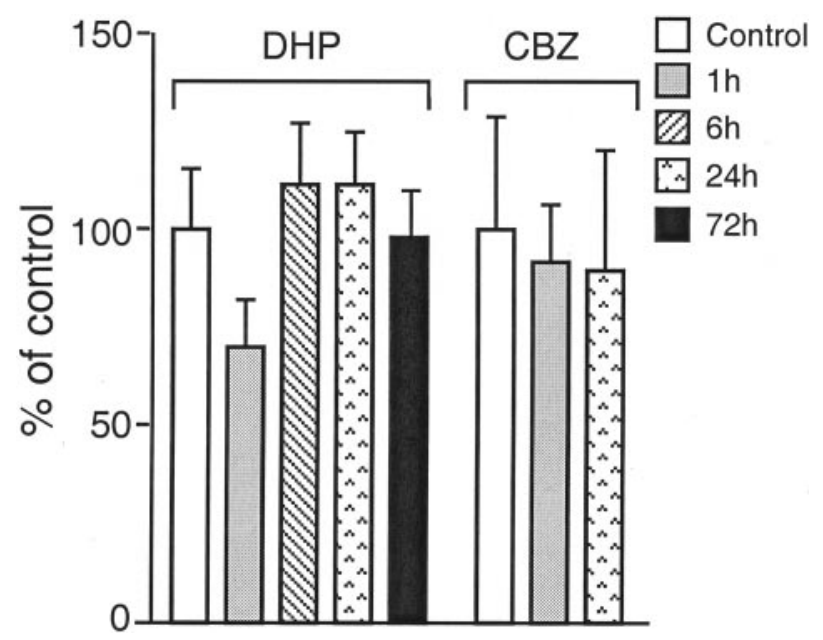

Figure 3. Effect of repetitive AED treatment on $m d r 1$ mRNA in the mouse hippocampus. Data are expressed as described in legend to Figure 2. Phenytoin $(D H P ; 30 \mathrm{mg} / \mathrm{kg})$, carbamazepine $(C B Z ; 15 \mathrm{mg} / \mathrm{kg})$, or their vehicle was injected intraperitoneally for 7 consecutive days as described in Materials and Methods, and mice were killed at the indicated times after the last drug administration.

No changes in mrpl mRNA, a different MDR-associated protein (Zaman et al., 1994), were found in the same brain tissues 3 and $24 \mathrm{hr}$ after seizures (data not shown).

We subsequently studied whether repetitive AED treatment induces $m d r 1$ mRNA in the brain. Figure 3 shows that transcript levels did not change in the hippocampus 1-72 hr after the last administration of $30 \mathrm{mg} / \mathrm{kg}$ phenytoin or $1-6 \mathrm{hr}$ after $15 \mathrm{mg} / \mathrm{kg}$ carbamazepine (each drug given for 7 consecutive days).

To monitor the AED levels in the brain at the time of $m d r 1$ mRNA analysis, we measured their concentrations in the hip-
Table 2. Tissue concentrations of phenytoin and carbamazepine in C57BL/6 mice at various times after $7 \mathrm{~d}$ of chronic administration

\begin{tabular}{lccl} 
& \multicolumn{3}{c}{$\begin{array}{l}\text { AED concentrations } \\
(\mu \mathrm{g} / \mathrm{ml} \text { or gm })\end{array}$} \\
\cline { 2 - 4 } Drug & $\begin{array}{c}\text { Time } \\
(\mathrm{hr})\end{array}$ & Hippocampus & Ratio $^{b}$ \\
\hline Phenytoin $^{a}$ & 1 & $46.6 \pm 6.0$ & $1.2 \pm 0.01$ \\
& 6 & $30.0 \pm 3.0$ & $1.3 \pm 0.04$ \\
& 24 & $7.7 \pm 2.0$ & $1.5 \pm 0.2$ \\
Carbamazepine & 72 & $\mathrm{ND}$ & \\
Carbamazepine-epoxide & 1 & $5.8 \pm 0.6$ & $2.4 \pm 0.4$ \\
& 6 & $\mathrm{ND}$ & \\
& 1 & $1.3 \pm 0.4$ & $1.1 \pm 0.06$ \\
& 6 & $\mathrm{ND}$ &
\end{tabular}

Data are means $\pm \operatorname{SE}(n=4)$.

${ }^{a}$ The tissue concentrations of its metabolite 5-(4-hydroxyphenyl)-5-phenytoin were below the limits of quantification of the analytical procedure.

${ }^{b}$ Hippocampus-to-plasma concentration ratio. ND, Not detectable. The AED levels are higher than those reported in Table 4, as expected after a chronic treatment protocol.

pocampus and plasma in a different group of mice $(n=4$ each group) treated with the AEDs for 7 consecutive days and killed 1-72 hr after the last administration. Table 2 shows that phenytoin concentrations in the hippocampus and plasma decreased in a time-dependent manner, and that the drug was not detectable in brain or plasma after $72 \mathrm{hr}$. Carbamazepine and 10,11carbamazepine-epoxide concentrations in the hippocampus were measurable at $1 \mathrm{hr}$ after the last dosing, whereas both drugs were not detected in tissue or in plasma at $6 \mathrm{hr}$.

We then studied whether changes in P-gp levels resulted in modifications in AED concentrations in the brain using two approaches: we used knock-out mice carrying disruption of the endogenous genes $m d r l a$ and $m d r l b$ leading to deficiency of both P-gps (Schinkel et al., 1994) or mice in which $m d r 1$ mRNA was overexpressed by seizures.

Table 3 shows phenytoin or carbamazepine and its metabolite concentrations in the hippocampus and plasma of knock-out mice lacking P-gp. Compared with their wild-type littermates, -/mice showed significantly higher concentrations of phenytoin in the hippocampus ( $+46 \%$ on average) both 1 and $4 \mathrm{hr}$ after 30 $\mathrm{mg} / \mathrm{kg}$ phenytoin. Plasma levels were not modified; thus the ratio between brain tissue and plasma was increased 1.6-fold in -/mice $(p<0.01)$.

The brain/plasma ratio was significantly increased at $1 \mathrm{hr}$ after treatment in the cerebellum (wild-type, $1.4 \pm 0.05 ;-/-, 2.0 \pm$ $0.2 ; p<0.01$ ) and at $4 \mathrm{hr}$ after treatment in the cortex (wild-type, $1.2 \pm 0.04 ;-/-, 1.5 \pm 0.06 ; p<0.01$ ). Phenytoin metabolite was below the limits of quantification of the analytical procedure both in brain and plasma.

Carbamazepine concentrations did not differ in the hippocampus of $-/-$ mice compared with wild-type mice $1 \mathrm{hr}$ after treatment. At $3 \mathrm{hr}$, carbamazepine levels were not detectable in wild-type mice but were 2.4- and 1.6-fold above the lower point of the calibration curve in the hippocampus and plasma of $-/-$ mice. 10,11-Carbamazepine-epoxide levels were significantly elevated in brain tissue of $-/-$ mice versus wild-type mice at both 1 and $3 \mathrm{hr}(p<0.01)$.

mRNA overexpression observed in the hippocampus $6 \mathrm{hr}$ after seizures resulted in a $30 \%$ decrease $(p<0.05)$ in the brain/ 
Table 3. Plasma and tissue concentrations of phenytoin and carbamazepine in $m d r l-/-$ mice and their wild-type littermates

\begin{tabular}{|c|c|c|c|c|c|}
\hline \multirow[b]{2}{*}{ Drug } & \multirow[b]{2}{*}{ Time (hr) } & \multirow[b]{2}{*}{ Genetic status } & \multicolumn{3}{|c|}{ AED concentrations $(\mu \mathrm{g} / \mathrm{ml}$ or $\mathrm{gm})$} \\
\hline & & & Hippocampus & Plasma & Ratio $^{c}$ \\
\hline \multirow[t]{4}{*}{ Phenytoin $^{a}$} & \multirow[t]{2}{*}{1} & Wild type & $26.4 \pm 1.0$ & $17.8 \pm 0.5$ & $1.5 \pm 0.1$ \\
\hline & & $m d r 1 a / b-/-$ & $38.2 \pm 2.4^{*}$ & $16.5 \pm 1.0$ & $2.4 \pm 0.3^{*}$ \\
\hline & \multirow[t]{2}{*}{4} & Wild type & $7.1 \pm 0.5$ & $12.9 \pm 0.4$ & $0.5 \pm 0.0$ \\
\hline & & $m d r 1 a / b-/-$ & $10.4 \pm 0.6^{*}$ & $13.2 \pm 0.5$ & $0.8 \pm 0.1^{*}$ \\
\hline \multirow[t]{8}{*}{ Carbamazepine $^{b}$} & \multirow[t]{4}{*}{1} & \multirow[t]{2}{*}{ Wild type } & $8.4 \pm 1.0$ & $3.9 \pm 0.4$ & $2.2 \pm 0.0$ \\
\hline & & & $(1.2 \pm 0.1)$ & $(0.8 \pm 0.1)$ & $(1.5 \pm 0.1)$ \\
\hline & & \multirow[t]{2}{*}{$m d r 1 a / b-/-$} & $6.2 \pm 0.8$ & $3.2 \pm 0.5$ & $2.1 \pm 0.1$ \\
\hline & & & $(1.4 \pm 0.2)$ & $(0.8 \pm 0.1)$ & $\left(2.2 \pm 0.1^{*}\right)$ \\
\hline & \multirow[t]{4}{*}{3} & \multirow[t]{2}{*}{ Wild type } & $<0.5$ & $<0.3$ & \\
\hline & & & $(<0.5)$ & $(<0.3)$ & \\
\hline & & \multirow[t]{2}{*}{$m d r 1 a / b-/-$} & $1.2 \pm 0.2^{*}$ & $0.4 \pm 0.1^{*}$ & $2.5 \pm 0.4$ \\
\hline & & & $\left(1.0 \pm 0.2^{*}\right)$ & $\left(0.3 \pm 0.1^{*}\right)$ & $(3.0 \pm 0.4)$ \\
\hline
\end{tabular}

Data are means \pm SE of five animals. mdr1a/b-/- mice are C57BL/6 mice lacking both isoforms of P-gp.

${ }^{a}$ The tissue concentrations of its metabolite 5-(4-hydroxyphenyl)-5-phenytoin were below the limits of quantification of the analytical procedure.

${ }^{b}$ The tissue concentrations of carbamazepine-epoxide are shown in parentheses.

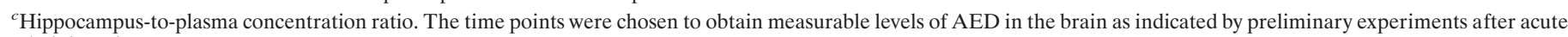
administration.

${ }^{*} p<0.01$ versus wild-type mice by Student's $t$ test or Mann-Whitney's test (for ratio values).

Table 4. Effect of P-gp overexpression by seizures on phenytoin brain disposition

Phenytoin concentration

\begin{tabular}{llll} 
& & & \\
\cline { 2 - 4 } Treatment & Hippocampus $(\mathrm{ng} / \mathrm{gm})$ & Ratio (brain/plasma) & Dialysate (ng/ml) \\
\hline Vehicle & $36,000 \pm 3915$ & $1.3 \pm 0.07$ & $21.1 \pm 1.7$ \\
Kainic acid & $26,480 \pm 3807$ & $0.9 \pm 0.06^{*}$ & $37.4 \pm 8.0$
\end{tabular}

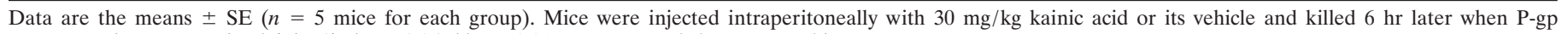
overexpression was maximal (Fig. 2). ${ }^{*} p<0.05$; ${ }^{*} p<0.01$ versus controls by Mann-Whitney test.

plasma ratio of phenytoin and in a 2.3 -fold increase in the extracellular drug concentration $(p<0.01)$ compared with naive mice (Table 4 ), as estimated by brain microdialysis.

Finally, to study whether $m d r 1$ expression was increased in brain tissue of chronically epileptic animals, we used rats that had developed self-sustained limbic SE after electrical stimulation of the hippocampus, representing a well established model of spontaneous seizures in rodents (Fountain et al., 1998; Gorter et al., 2001). Figure 4 depicts the increase in the level of mdr1 mRNA in the stimulated hippocampus and contralateral entorhinal cortex of rats 3 months after induction of SE. The entorhinal cortex was chosen because it is a limbic area that is significantly recruited in seizure generalization in this model (Fountain et al., 1998).

The average duration of SE in stimulated rats was $10.5 \pm 2.4 \mathrm{hr}$ $(n=6)$ as assessed by continuous on-line EEG recording after electrical stimulation as described previously in detail (Gorter et al., 2001). The average number of spontaneous seizures observed during the last week of recording before killing was $8.0 \pm 1.6$ seizures/d. Mdr1 mRNA levels were significantly increased in both regions (1.8-fold in the hippocampus and fivefold on average in the entorhinal cortex; $p<0.01$ ). No significant changes in $m d r 1$ mRNA levels were found in non-SE rats (data not shown). The electrical stimulation did not induce SE but only short-lasting seizure activity in these rats $(0.1 \pm 0.05 \mathrm{hr} ; n=5)$, and these same rats rarely show late spontaneous seizures (for more details, see Gorter et al., 2001).

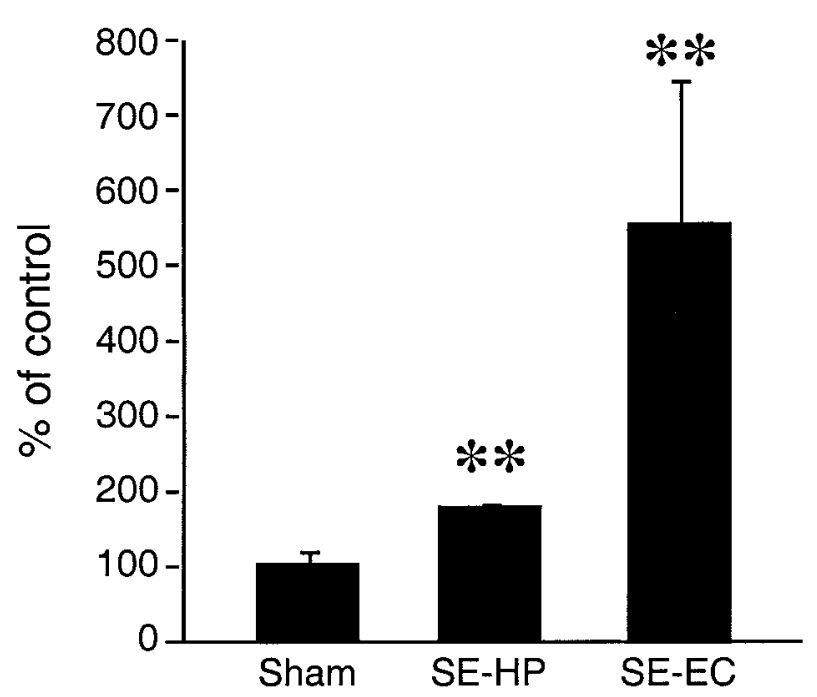

Figure 4. Mdr1 mRNA levels in the hippocampus and entorhinal cortex of rats with spontaneous seizures. Data are means \pm SE $(n=5-6)$ of optical density values of gel bands representing PCR amplification products of $m d r 1$ mRNA normalized to the corresponding $\beta$-actin band used in each sample as an internal standard. Values in spontaneously epileptic rats $(S E)$ are expressed as a percentage of control levels [sham-stimulated rats (Sham)]. HP, Stimulated hippocampus (1.8-fold increase); EC, contralateral entorhinal cortex (5.5-fold increase). ${ }^{* *} p<0.01$ versus sham by Mann-Whitney's test. 


\section{DISCUSSION}

This study shows that limbic seizures that are relatively resistant to AED treatment (Reynolds, 1987; Hauser and Hesdorffer, 1990; Loscher, 1997) induce $m d r 1$ mRNA to a large extent in limbic areas. This increase appears to be specific, because mrp1, a different P-gp involved in MDR (Zaman et al., 1994), was unchanged. $M d r 1$ mRNA overexpression in kainate-injected mice was transient but outlasted their acute seizures by several hours, suggesting that ongoing epileptic activity may result in sustained increase of this protein.

This was confirmed by measuring $m d r 1$ mRNA levels in epileptic tissue from spontaneously epileptic rats. Thus, in these animals $m d r 1$ mRNA expression was enhanced 3 months after the acute SE both in the hippocampus, where seizures were initially triggered, and in the entorhinal cortex, an area involved in seizure generalization and spread (Fountain et al., 1998). These findings clearly indicate that spontaneously recurring limbic seizures are associated with elevated levels of mRNA of this transport protein. Recent studies have indeed shown overexpression of MDR1 in the epileptic focus obtained at surgery from drug-refractory epileptic patients (Tishler et al., 1995).

P-gp is membrane bound and highly expressed in secretory epithelia in a variety of peripheral tissues (Thiebaut et al., 1987), and it is expressed at relatively low levels in normal brain by endothelial cells at the blood-brain barrier (Cordon-Cardo et al., 1989). Specific immunoreactivity was found on astrocytic-like foot processes around blood vessels (Tishler et al., 1995; Golden and Pardridge, 1999; Sisodiya et al., 1999, 2001).

Increased P-gp has been observed in various pathological conditions associated with drug-resistant epilepsy in humans. Thus, P-gp immunoreactive glia were found in brain tissue from epilepsy patients with malformations of cortical development (Sisodiya et al., 1999) or in tuber cells in tuberous sclerosis (Lazarowski et al., 1999). Both endothelial and glial cells (astrocytes) appear to overexpress the pump in human epileptic and rat brain tissue (Sisodiya et al., 1999; Zhang and Lee, 1999; Rizzi et al., 2001).

The evidence that both phenytoin and carbamazepine accumulate in the brains of knock-out mice lacking the $m d r l$ gene to a larger extent than in wild-type mice indicates that these AEDs are indeed substrates of this pump. Accordingly, Schinkel et al. (1996) and Tishler et al. (1995) have reported previously that phenytoin is transported both by human MDR1 and by rodent mdrla P-gp in transfected cells. Our findings are in line with recent evidence by Potschka et al. (2001), who demonstrated in vivo that carbamazepine is a substrate of $\mathrm{P}$-gp using brain microdialysis in rodents and blockers of P-gp function. Moreover, mice lacking one isoform of this transport protein ( $m d r 1 a-/-)$ accumulate significantly less carbamazepine and various AEDs in their brain compared with wild-type littermates (Sills and Kwan, 2001).

In contrast, Owen et al. (2001) did not find changes in carbamazepine levels in the brains of $m d r 1 a / b-/-$ mice versus wild-type mice. However, these authors measured levels of the AEDs in the entire brain, whereas we have shown here that the extent of changes in AED levels is area-specific. Moreover the time points at which they measured carbamazepine ( 1 and $4 \mathrm{hr}$ ) may not be optimal to reveal the differences using whole-brain tissue (see present data).

Schinkel et al. (1994) showed that the most pronounced pharmacological effect of mdrla inactivation was in the brain, indicat- ing that P-gp plays an important transporter role in the bloodbrain barrier and possibly in brain tissue as well.

Resistance to treatment can be an intrinsic feature of the disease itself or can be acquired after treatment with AEDs. We therefore studied whether chronic AED treatment may per se affect the expression of the pump. At therapeutic doses, both phenytoin and carbamazepine appear to be ineffective on the levels of $m d r 1$ mRNA, thus suggesting that seizure activity is likely to be the main determinant in enhancing P-gp gene expression in epilepsy rather than AED treatment.

P-gp acts as an ATP-dependent drug efflux system in the cells. The overall P-gp activity controlling drug transport is dependent on two parameters: (1) the level of expression of the $m d r 1$ gene determining the amount of protein that is synthesized in the cells (Endicott and Ling, 1989) and (2) the functionality of the $m d r 1$ encoded P-gp, which determines which substrates are recognized and transported (Gottesman and Pastan, 1993). Sensitivity of tumor cells toward chemotherapy often correlates inversely with increased $m d r 1$ expression (Goldstein et al., 1989; Pirker et al., 1991).

To assess whether brain P-gp overexpression was functionally relevant for influencing local AED concentrations, we studied the whole tissue as well as the extracellular concentration of phenytoin at the time of maximal $m d r l$ mRNA increase after acute seizures in mice. The brain/plasma ratio of phenytoin was drastically reduced and its extracellular disposition was increased in mice treated previously with kainic acid.

This evidence suggests that the function of the pump is modified by seizures as a reflection of its enhanced synthesis. Increased P-gp would impair drug access to its target sites on neurons at two consecutive steps: (1) at the level of the endothelial cells of the brain capillaries thus, leading to decreased tissue concentrations (Munari et al., 1994), and (2) at the level of the astrocytic endfoot processes ensheathing brain capillaries and surrounding neurons. This would determine a dynamic net flux of the drug from the neurons back to the blood stream and may result in less drug being available for interactions with its receptor or acceptor sites in neurons. Increased drug in dialysate, vis-à-vis with decreased whole-tissue levels, likely reflects a reservoir-like effect caused by its enhanced extrusion from brain parenchyma when the P-gp is functionally activated.

Epileptic activity may enhance P-gp as a defensive mechanism to extrude toxic compounds produced within the brain or entering the brain from the blood (Nitsch et al., 1986). This induction may occur to a larger extent in predisposed individuals [i.e., with defective mechanisms controlling MDR1 gene expression (Gottesman and Pastan, 1993)]. In this regard, a functional polymorphism of the human MDR gene has been found to correlate with the expression level and function of this protein (Hoffmeyer et al., 2000).

If the P-gp plays a significant role as one of the factors contributing to MDR, then it will be important to develop new AEDs that are not substrates of this pump and/or exploit pharmacological treatments aimed at inhibiting its function (Rivoltini et al., 1990; Lemaire et al., 1996; Desrayaud et al., 1998; Dantzig et al., 2001) to ameliorate the efficacy of AEDs in patients refractory to current therapies. In this regard, it is interesting to note that kainate seizures did not affect $m d r 1$ mRNA in the cerebellum, a brain area not directly involved in epileptic activity in this model but known to mediate many side-effects of AEDs. Thus, the area-specific increase in $\mathrm{P}$-gp raises the possibility that blockers of 
this transport pump may ameliorate the therapeutic efficacy of AEDs without simultaneously increasing their toxicity.

\section{REFERENCES}

Bendotti C, Vezzani A, Serafini R, Servadio A, Rivolta R, Samanin R (1991) Increased preproneuropeptide Y mRNA in the rat hippocampus during the development of hippocampal kindling: comparison with the expression of preprosomatostatin mRNA. Neurosci Lett 132: $175-178$.

Cockerell OC, Johnson AL, Goodridge DMG, Sander JWAS, Shorvon SD (1995) The remission of epilepsy: results from the rational General Practise Study of Epilepsy. Lancet 346:140-144.

Collaborative Group for the Study of Epilepsy (1992) Prognosis of epilepsy in newly referred patients: a multicenter prospective study of the effects of monotherapy on the long-term onset of epilepsy. Epilepsia 93:45-51.

Cordon-Cardo C, O'Brien JP, Casals D, Rittman-Grauer L, Melamed MR, Bertino JR (1989) Multidrug-resistance gene (P-glycoprotein) is expressed by endothelial cells at blood-brain barrier sites. Proc Natl Acad Sci USA 86:695-698.

Croop JM, Raymond M, Haber D, Devault A, Arceci RJ, Gros P, Housman DE (1989) The three mouse multidrug resistance (mdr) genes are expressed in a tissue-specific manner in normal mouse tissues. Mol Cell Biol 9:1346-1350.

Dantzig AH, Law KL, Cao J, Starling JJ (2001) Reversal of multidrug resistance by the P-glycoprotein modulator, LY335979, from the bench to the clinic. Curr Med Chem 8:39-50.

Desrayaud S, De Lange ECM, Lemaire M, Bruelisauer, De Boer AG, Breimer DD (1998) Effect of the mdr1a P-glycoprotein gene disruption on the tissue distribution of SDZ PSC 833, a multidrug resistancereversing agent in mice. J Pharmacol Exp Ther 285:438-443.

Endicott JA, Ling V (1989) The biochemistry of P-glycoproteinmediated multidrug resistance. Annu Rev Biochem 58:137-171.

Fountain NB, Bear J, Bertram EH, Lothman EW (1998) Responses of deep entorhinal cortex are epileptiform in an electrogenic rat model of chronic temporal lobe epilepsy. J Neurophysiol 80:230-240.

Frey HH, Janz D (1985) Antiepileptic drugs. In: Handbook of experimental pharmacology 74 (Frey H-H, Janz D, eds), pp 351-419, 479506. Berlin: Springer.

Golden PL, Pardridge WM (1999) P-glycoprotein on astrocyte foot processes of unfixed isolated human brain capillaries. Brain Res 819: 143-146.

Goldstein LJ, Galski H, Fojo A, Willingham M, Lai SL, Gadzar A, Pirker R, Green A, Crist W, Brodeur GM (1989) Expression of multidrug resistance gene in human cancers. J Natl Cancer Inst 81:116-124.

Gorter JA, van Vliet EA, Aronica E, Lopes da Silva FH (2001) Progression of spontaneous seizures after status epilepticus is associated with mossy fibre sprouting and extensive bilateral loss of hilar parvalbumin and somatostatin-immunoreactive neurons. Eur J Neurosci 13:657-669.

Gottesman MM, Pastan I (1993) Biochemistry of multidrug resistance mediated by the multidrug transporter. Annu Rev Biochem 62:385-427.

Hauser WA, Hesdorffer DC (1990) Epilepsy: frequency, causes, and consequences, pp 197-243. Landover, MD: Epilepsy Foundation of America.

Hoffmeyer S, Burk O, von Richter O, Arnold HP, Brockmoller J, Johne A, Cascorbi I, Gerloff T, Roots I, Eichelbaum M, Brinkmann U (2000) Functional polymorphisms of the human multidrug-resistance gene: multiple sequence variations and correlation of one allele with P-glycoprotein expression and activity in vivo. Proc Natl Acad Sci USA 97:3473-3478.

Juliano RL, Ling V (1998) A surface glycoprotein modulating drug permeability in Chinese hamster ovary cell mutants. Biochim Biophys Acta 455:152-162.

Lazarowski A, Sevlever G, Taratuto A, Massaro M, Rabinowicz A (1999) Tuberous sclerosis with MDR1 gene expression and drug-resistant epilepsy. Pediatr Neurol 21:731-734.

Lemaire M, Bruelisauer A, Guntz P, Sato H (1996) Dose-dependent brain penetration of SDZ PSC833, a novel multidrug resistancereversing cyclosporin, in rats. Cancer Chemother Pharmacol 38:481-486.

Liu H, Delgado M, Forman LJ, Eggers CM, Montoya JL (1993) Simultaneous determination of carbamazepine, phenytoin, phenobarbital, primidone and their principal metabolites by high-performance liquid chromatography with photodiodide-array detection. J Chromatogr 616:105-115.

Lombardo AJ, Kuzniecky R, Powers RE, Brown GB (1996) Altered brain sodium channel transcript levels in human epilepsy. Mol Brain Res 35:84-90.

Loscher W (1997) Animal models of intractable epilepsy. Prog Neurobiol 53:239-258

Martin C, Berridge G, Higgins CF, Mistry P, Charlton P, Callaghan R (2000) Communication between multiple drug binding sites on P-glycoprotein. Mol Pharmacol 58:624-632.

Morrow CS, Cowan KH (1988) Mechanisms and clinical significance of multidrug resistance. Oncology 2:55-63.

Munari C, Hoffmann D, Francione S, Kahane P, Tassi L, Lo Russo G, Benabid AL (1994) Stereo-electro-encephalo-graphy methodology: advantages and limits. Acta Neurol Scand 152:56-67.

Nitsch C, Goping G, Klatzo I (1986) Pathophysiological aspects of blood-brain barrier permeability in epileptic seizures. In: Advances in experimental medicine and biology (Schwarcz R, Ben-Ari Y, eds), pp 175-184. New York: Academic.

Owen A, Pirmohamed M, Tettey JN, Chadwick D, Kevin P (2001) Carbamazepine is not a substrate for P-glycoprotein. Br J Clin Pharmacol 51:345-349.

Pirker R, Wallner J, Geissler K, Linkesch W, Haas OA, Bettelheim P, Hopfner M, Scherrer R, Valent P, Havelec L (1991) MDR1 gene expression and treatment outcome in acute myeloid leukemia. J Natl Cancer Inst 83:708-712.

Potschka H, Fedrowitz M, Loscher W (2001) P-glycoprotein and multidrug resistance-associated protein are involved in the regulation of extracellular levels of the major antiepileptic drug carbamazepine in the brain. NeuroReport 12:3557-3560.

Racine RJ (1972) Modification of seizure activity by electrical stimulation. II. Motor seizure. Electroencephalogr Clin Neurophysiol 32:281-294.

Reynolds EM (1987) Early treatment and prognosis of epilepsy. Epilepsia 28:97-106.

Rivoltini L, Colombo MP, Supino R, Ballinari D, Tsuruo T, Parmiani G (1990) Modulation of multidrug resistance by verapamil or mdr1 antisense oligodeoxynucleotide does not change the high susceptibility to lymphokine-activated killers in mdr-resistant human carcinoma (LoVo) line. Int J Cancer 46:727-732.

Rizzi M, Guiso G, Mulé F, Moneta D, Sperk G, Vezzani A, Caccia S 2001) Induction of MDR-1 by limbic seizures in mice: relevance for drug resistance in epilepsy. Soc Neurosci Abstr 27:553.2.

Sashihara S, Yanagihara N, Kobayashi H, Izumi F, Tsuji S, Murai Y, Mita $\mathrm{T}$ (1992) Overproduction of voltage-dependent $\mathrm{Na}^{+}$channels in the developing brain of genetically seizure-susceptible E1 mice. Neuroscience 48:285-291.

Schinkel AH, Smit JJM, van Tellinger O, Beijnen JH, Wagenaar E, van Deemter L, Mol CAAM, van der Valk MA, Robanus-Maandag EC, te Riete HPJ, Berns AJM, Borst P (1994) Disruption of the mouse mdr1a P-glycoprotein gene leads to a deficiency in the blood-brain barrier and to increased sensitivity to drugs. Cell 77:491-502.

Schinkel AH, Wagenaar E, Mol CA, van Deemter L (1996) P-glycoprotein in the blood-brain barrier of mice influences the brain penetration and pharmacological activity of many drugs. J Clin Invest 97:2517-2524.

Sills GJ, Kwan P (2001) P-glycoprotein-mediated antiepileptic drug transport: a role in refractory epilepsy? Epilepsia 42 [Suppl 7]:83.

Sisodiya SM, Heffernan J, Squier MV (1999) Over-expression of P-glycoprotein in malformation of cortical development. NeuroReport 10:3437-3441.

Sisodiya SM, Lin W-R, Squier MV, Thom M (2001) Multidrugresistance protein 1 in focal cortical dysplasia. Lancet 357:42-43.

Spreafico R, Battaglia G, Arcelli P, Andermann F, Dubeau F, Palmini A, Olivier A, Villemure JG, Tampieri G, Avanzini G, Avoli M (1998) Cortical dysplasia. An immunocytochemical study of three patients. Neurology 50:27-36.

Thiebaut F, Tsuruo T, Hamada H, Gottesman MM, Pastan I, Willingham MC (1987) Cellular localization of the multidrug-resistance gene product P-glycoprotein in normal human tissues. Proc Natl Acad Sci USA 84:7735-7738

Tishler DM, Weinberg K, Hinton DR, Barbaro N, Annett GM, Raffel C (1995) MDR1 gene expression in brain of patients with medically intractable epilepsy. Epilepsia 36:1-6.

Zaman GJR, Flens MJ, van Leusden MR, de Haas M, Mulder HS, Lankelma J, Pinedo HM, Scheper RJ, Baas F, Broxterman HJ, Borst P (1994) The human multidrug resistance-associated protein MRP is a plasma membrane drug-efflux pump. Proc Natl Acad Sci USA 91:8822-8826.

Zhang L, Ong W Y, Lee T (1999) Induction of P-glycoprotein expression in astrocytes following intracerebroventricular kainate injections. Exp Brain Res 126:509-516. 